Hist. Phil. Life Sci., 25 (2003), 83-111

\title{
Evolutionary Ethics from Darwin to Moore
}

\author{
Fritz Allhoff \\ Department of Philosophy, \\ University of California, \\ Santa Barbara, CA 93106, USA
}

ABSTRACT - Evolutionary ethics has a long history, dating all the way back to Charles Darwin. ${ }^{1}$ Almost immediately after the publication of the Origin, an immense interest arose in the moral implications of Darwinism and whether the truth of Darwinism would undermine traditional ethics. Though the biological thesis was certainly exciting, nobody suspected that the impact of the Origin would be confined to the scientific arena. As one historian wrote, 'whether or not ancient populations of armadillos were transformed into the species that currently inhabit the new world was certainly a topic about which zoologists could disagree. But it was in discussing the broader implications of the theory...that tempers flared and statements were made which could transform what otherwise would have been a quiet scholarly meeting into a social scandal' (Farber 1994, 22). Some resistance to the biological thesis of Darwinism sprung from the thought that it was incompatible with traditional morality and, since one of them had to go, many thought that Darwinism should be rejected. However, some people did realize that a secular ethics was possible so, even if Darwinism did undermine traditional religious beliefs, it need not have any effects on moral thought. ${ }^{2}$

Before I begin my discussion of evolutionary ethics from Darwin to Moore, I would like to make some more general remarks about its development. ${ }^{3}$ There are three key events during this history of evolutionary ethics. First, Charles Darwin published On the Origin of the Species (Darwin 1859). Since one did not have a fully developed theory of

* Portions of this paper have been presented at the meeting of the International Society for the Philosophy, History, and Social Studies of Biology (Vienna, Austria, 2003), and at the International Congress of Logic, Methodology, and Philosophy of Science (Oviedo, Spain, 2003). In addition to the conference participants, I would like to thank Michael Bradie, Matthew Hanser, Richard Glatz, and two anonymous reviewers for their helpful comments on earlier drafts.

${ }^{1}$ It could even be argued that evolutionary ethics has its origins before Darwin, most plausibly in the works of Thomas Hobbes and David Hume. Certainly many of Hobbes's writings echo ideas present in modern day sociobiology, and Hume's empiricism is also congenial to naturalized approaches to morality.

2 John Stuart Mill's Utilitarianism was published in 1861, just two years after the Origin and received a tremendous reception within British society. As Kant was less known within Great Britain, and often unavailable in translation, Mill offered the first widely available attempt at secular ethics.

${ }^{3}$ It should also be observed that there were historical contributions from continental sources, most notably Lamarck and Haeckel. While these thinkers made valuable (and creative!) contributions to the debate, I shall nonetheless largely exclude them from my discussion, though certainly someone should write about them. Within contemporary philosophy of biology, these thinkers have probably been less influential, though this is no doubt because most contemporary philosophers of biology have radiated from the Anglo-American tradition. The views that I will consider are therefore more representative of the historical influence upon many contemporary theorists, though this phenomenon certainly carries no normative weight 
evolution until 1859, there exists little work on evolutionary ethics until then. ${ }^{4}$ Shortly thereafter, Herbert Spencer (1898) penned the first systematic theory of evolutionary ethics, which was promptly attacked by T.H. Huxley (Huxley 1894). Second, at about the turn of the century, moral philosophers entered the fray and attempted to demonstrate logical errors in Spencer's work; such errors were alluded to but never fully brought to the fore by Huxley. These philosophers were the well known moralists from Cambridge: Henry Sidgwick (Sidgwick 1902, 1907) and G.E. Moore (Moore 1903), though their ideas hearkened back to David Hume (Hume 1960). These criticisms were so strong that the industry of evolutionary ethics was largely abandoned (though with some exceptions) for many years. ${ }^{5}$ Third, E.O. Wilson, a Harvard entomologist, published Sociobiology: The New Synthesis in 1975 (Wilson E.O. 1975), which sparked renewed interest in evolutionary ethics and offered new directions of investigation. These events suggest the following stages for the history of evolutionary ethics: development, criticism and abandonment, revival. In this paper, I shall focus on the first two stages, since those are the ones on which the philosophical merits have already been largely decided. The revival stage is still in progress and we shall eventually find out whether it was a success.

\section{Charles Darwin}

In constructing a history of evolutionary ethics, it is only appropriate to start with Darwin himself. Darwin's legacy certainly lies in his contributions to science, but morality was always a topic in which he was very interested; his journals and correspondences often discuss the topic. ${ }^{6}$ In his published work, however, Darwin did not mention morality until he published The Descent of Man in 1871. Oddly, Darwin did not even discuss humans at all in the Origin, aside from the one prophetic claim that 'light will be thrown on the origin of man and his history' (Darwin 1871, 488). He certainly was aware of the implications his theory would have for humans, yet he chose not to make his first great work more controversial than necessary.7 When he

4 If there was an exception to this claim, it would be found in the work of Charles Darwin's grandfather, Erasmus Darwin. Erasmus was an early evolutionist, and his moral views were borne from his evolution, though neither his version of evolution nor his thoughts on morality were systematic or very convincing. See (Darwin E. 1803, 295-314). Michael Ruse also discusses Erasmus Darwin's views (Ruse 1999, 435-437).

${ }^{5}$ In fact, some have argued that evolutionary ethics was not only abandoned, but presumed dead. See Ruse 1986a, 95-112.

${ }^{6}$ Fortunately for historians, nearly all of Darwin's private writings have been preserved. See (Darwin F. 1969). His private journals have also been published as Charles Darwin's Notebooks, 1830-44, ed. P. Barrett et al. (Ithaca: Cornell University Press, 1986). In addition to being interested in the genesis of morality, Darwin was also very much repulsed by slavery, and criticized the practice often. Many years after leaving South America, where he saw slavery, he wrote 'distant screams' still reminded him of the terrible conditions under which slaves lived. Darwin (1986), p. 496.

7 All Darwin's life, he had an immense dislike of conflict and never wanted to rock the boat. He even held off publication of the Origin for over twenty years, many of which he spent researching barnacles, 
finally did turn to humans in the Descent, his theory of evolution by natural selection had already gained substantial support, though certainly there were still detractors. In this later work, an entire chapter was dedicated exclusively to Darwin's thoughts on morality.

When scholars have considered Darwin's thoughts on morality, they have focused on his discussions in the Descent, which are primarily about the evolution of man's 'moral sense'. Even this treatment, however, is far from systematic, and contains long and frequent digressions into anthropological claims about various societies. For these reasons, Darwin has never received much attention as a moral thinker, and most histories of evolutionary ethics typically begin with his contemporary and countryman, Herbert Spencer. I think that these customs, both the focus on the Descent and the marginalization of Darwin's views on ethics, are unfortunate for two reasons. First, Darwin clearly discussed morality in other writings, most particularly his ' $\mathrm{M}$ ' (metaphysical) notebook. Secondly, I think that he actually comes closer to recognizing the significance of evolution for ethics than later writers (especially Spencer), and he certainly avoids making their logical errors.

Darwin kept many notebooks and, while the ' $\mathrm{D}$ ' notebook was devoted to his scientific theory, his ' $M$ ' notebook was devoted to its wider consequences. 8 Both of these notebooks were begun in 1838, the year he first conceived evolution by natural selection, and therefore predate the Descent by over three decades. Though there is little in the way of cohesive argumentation, we can at least surmise some of Darwin's general ideas. He certainly thought that the evolution of morality was something that was to be explained historically, by a discussion of the natural history of man. Just as evolutionary forces led to the development of the eye, so they also did to the development of morality. Moral philosophers might find this to be an odd use of the word morality, that morality itself has nothing to do with the development of humans, or even that morality need not require humans at all. Darwin certainly did not think that actual moral obligation was created by evolution, rather he thought that man's 'moral sense' was shaped by evolutionary pressures. Therefore, some people might rather look at Darwin's comments on the moral

because of his anxiety as to how his work would be received. It was only after another evolutionist, Alfred Russel Wallace, appeared to be closing in on Darwin's theory of natural selection that he finally rushed to the presses.

8 Desmond and Moore 1991, 258. He even wrote in his 'M' notebook that 'Origin of man now proved.-Metaphysics must flourish.-He who understands baboon would do more towards metaphysics than Locke.' Notebooks M74. 
sense as a discussion of moral psychology and its origins, rather than having to do with morality itself. However, it is not clear that Darwin, or even contemporary philosophers who adopt a naturalized approach to morality, would really see a difference. In fact, everything that he writes is consistent with, though not necessarily suggestive of, objective morality being completely illusory.

Darwin never actually says what he means by moral sense, but his examples seem pretty clearly to suggest that what he has in mind are our intuitions, natural sympathies, and 'moral' emotions (e.g., shame, anger, pride, vengeance, etc.). ${ }^{9}$ The development of the moral sense he sees as being clearly connected to the nature of man as a social animal; he thought that, given any social animal, the development of a moral sense was inevitable. ${ }^{10}$ But why? Certainly the moral sense helps to create social cohesion and more harmonious living. For example, the intuition that theft is wrong, coupled with the guilt that such an act can be expected to produce, means that we are less likely to steal than we would absent our moral sense (and lack of theft makes for more a more desirable social existence). Given the societal (not individual!) benefits of the moral sense, he thought that evolution could have taken instincts from our ancestors and gradually strengthened them over time, eventually reaching the powerful moral sense that we currently possess. Darwin went so far as to say that from natural instincts alone, it was possible to derive 'all that is most beautiful in the moral sentiments.'11

Since these ideas were kept in Darwin's private journals, the general pubic was obviously not aware of them. However, in the years between Darwin's publications of the Origin and the Descent, some others began to wonder what implications natural selection might have for morality, and these ideas did become widely available. Darwin's cousin, Francis Galton, wrote an article in a popular magazine which discussed the heredity of mental and moral characteristics (Galton 1865). Galton wondered whether the operation of natural selection could be extended from physical traits to mental and moral ones. If these latter traits could confer advantages in the struggle for existence (and if they were heritable), there would be no reason to think that natural selection could not select for them. ${ }^{12}$ Also

${ }^{9}$ For example, he writes that we have our emotions, like revenge and anger, because they benefited our ancestors. Notebooks M122-123.

10 Notebooks M120-121.

11 Notebooks N5.

12 Walter, Bagehot, These articles were later republished in his Physics and Politics, or Thoughts on the Application of the Principles of 'Natural Selection' and 'Inheritance' to Political Society (London: H. S. King, 1872). 
in the late 1860's, Walter Bagehot argued that 'virtues' such as obedience, honesty, and valor offered survival advantages and could therefore be the results of natural selection (Farber 1994, 15).

With the publication of the Descent, Darwin finally laid out his views on morality and made them known to the general public. This work tackled the thorny issue of the evolution of man, which Darwin knew was going to be just as controversial as his theory of natural selection. In it, he presented evidence for the similarities between man and other animals, and he claimed that, of all the animals, man was most closely related to chimpanzees and gorillas. But, for philosophers, the most interesting part of the book is most likely the fourth chapter, which he dedicated exclusively to discussion of man's moral sense. The ideas that Darwin presented here are perhaps somewhat more mild than the ones which he offered in his private journals (which is certainly understandable!), but they are also more systematic.

He begins this chapter by recognizing the significance of the moral sense: '[O]f all the differences between man and the lower animals, the moral sense or conscience is by far the most important.'(Darwin $1871,100)$ This is also the closest that Darwin comes to saying exactly what he means by the moral sense, which he equates to our conscience. As I said above, I think that our intuitions, natural sympathies, and our moral emotions are the features that contemporary moral philosophers would most readily associate with Darwin's conception of the moral sense but, for him, all of these were tied into the notion of conscience. The evolution of morality was, for Darwin, the evolution of man's conscience. ${ }^{13}$

Also in the way of preliminaries, Darwin speculates that 'any animal whatever, endowed with well-marked social instincts, the parental and filial affections being here included, would inevitably acquire a moral sense or conscience, as soon as its intellectual powers had become as well, or nearly as well endowed, as in man.' (Darwin 1871, 100) Though it is doubtful that he had any scientific data to substantiate this claim, it is interesting to see that Darwin saw morality as necessarily emerging from the coupling of social instincts with intellect.14 So long as we grant that all social beings will have social instincts, which seems likely, it would therefore be impossible for intelligent beings to not feel the pull of morality. This conclusion

\footnotetext{
13 For a similar view, see (Thompson 1999, 475-476).

14 There could, I suppose, be social instincts without intellect, such as the instincts of the worker bee to serve the queen.
} 
would be consistent with recent studies by anthropologists, who have noted that no human society has been observed to completely lack moral norms (though the norms themselves vary somewhat). 15

One notable feature of Darwin's moral view is its reliance on group, rather than individual selection. For example, consider courage. Darwin would want to say that courage (which we think is a virtue), is an evolved characteristic and the reason it evolved is its contribution to fitness. But, we could ask, the fitness of whom? Clearly courage is not always does not always contribute to the fitness of its possessor. Imagine that we have a society which exists in competition with other nearby societies, and therefore needs (courageous) soldiers for its protection. Imagine that we were to take two men, who were equal in all but one respect: the first had the courage to answer the call to defend his society, whereas the second did not and therefore chose another profession. It seems clear that the life expectancy of the soldier would be shorter than the life expectancy of the non-soldier. Therefore, courage would not actually make its possessor more fit (in terms of reproductive success), ${ }^{16}$ but rather less.

Darwin, however, wants to maintain that courage does increase fitness, since it is part of his theory that our moral sense evolves because of selection pressures. Since courage does not increase the fitness of its possessor, he would need to measure fitness in a different way, which is how he landed at group selection. He wrote that:

It must not be forgotten that although a high standard of morality gives but a slight advantage to each individual man and his children over the other men of the same tribe, yet that an increase in the number of well-endowed men and advancement in the standard of morality will certainly give an immense advantage to one tribe over another. There can be not doubt that a tribe including many members who, from possessing in a high degree the spirit of patriotism, fidelity, obedience, courage, and sympathy, were always ready to give aid to each other and to sacrifice themselves for the common good, would be victorious over most other tribes, and this would be natural selection. At all times throughout the world tribes have supplanted other tribes; and as morality is one important element in their success, the standard of morality and the number of well-endowed men will thus everywhere tend to rise and increase (Darwin 1871, 166).

15 A wonderful book this discusses this topic is Matt Ridley's The Origins of Virtue: Human Instincts and the Evolution of Cooperation. Ridley not only points out that no human society lacks moral norms, but makes the stronger claim that many moral norms are universal among all human societies. Examples are prohibitions on killing and stealing, as well as the expectation that respect should be shown to parents. See also Brown 1991.

${ }^{16}$ Let us assume that there are not other factors involved, such as the soldier appearing more attractive to members of the opposite sex. 
For example, imagine that there are now two groups, only one of which has some members who are courageous and therefore become soldiers. The group that has soldiers would be able to protect itself and would therefore persist, whereas the other group would have no such protection and would perish. Thus courage increases the fitness of the group whose individuals possess it, while not benefiting those individuals themselves (and even perhaps harming them). As Darwin indicated, such stories could be told about any number of virtues.

Thus Darwin thought that, by invoking group selection, he could come up with the selection pressures that would have led to the formation of modern man's moral sense. Unfortunately, group selection is largely unpopular in biological circles; even if moral philosophers were to find Darwin's tale compelling, many evolutionary biologists would likely reject it out of hand. ${ }^{17}$ The reason group selection is unpopular is that it is obviously the individual, not the group, that carries the material (genes) on which natural selection operates. So, if an individual could benefit at the expense of the group, selection would favor his proliferation (or, more precisely, the proliferation of his genes); selfish individuals would come to dominate the population. Even those who support group selection would acknowledge the intra-group advantages of selfish behavior and would posit associative selection pressures, they would then have to establish contrary inter-group pressures that would oppose (i.e., diminish or outweigh, depending on their strength) the intra-group pressures. Regardless, there exist at least one set of selection pressures that, at best, weaken Darwin's account and, at worst, make it implausible.

Darwin himself was never comfortable with his reliance on group selection; the only way to reconcile it with his biological views was to look at the group as some sort of super-organism, which certainly seems to be a stretch (Ruse 2001, 206). Nevertheless, he had observed insect colonies where some members were sterile (e.g., wasps, bees, and ants), and he thought that this gave support to group selection. If selection operated on the individual, rather than the group, one would not expect to see sterile beings. So Darwin thought that the existence

17 Group selection was powerfully challenged (William 1966). Richard Dawkins has continued the assault against group selection, and even against the traditional understanding of individual selection, by arguing that selection operates on the level of the gene rather than the group (or even the individual), see (Dawkins 1982a and 1982b). Elliott Sober and David Sloan Wilson have attempted to resuscitate group selection by presenting a more sophisticated model than the naive version which was commonly exorcised since Williams's work. However, some critics regard their revised version as a theoretical possibility but unlikely to have played a substantial role in the evolution of most species. See (Sober 1984), (Wilson 1989, 257-272), and (Wilson and Sober 1994, 585-654; 1998). 
of such creatures lent credibility to group selection. ${ }^{18}$ Nevertheless, he was never fully comfortable with this notion, and was worried that it undermined his theory.

Also in the Descent, Darwin argued that the moral sense would evolve in four stages. First, protohumans would develop a set of social instincts that would unify them into a common society. Secondly, the individuals in the society would develop sufficient intellects to tend to these instincts, even in the presence of other urges. Remember that, for Darwin, morality and intellect developed together; the former was a consequence of the latter, so until sufficient intelligence evolved in man, morality would be impossible. Third, language would have to evolve so that society members could communicate with each other. And finally, society members would develop habits of caring for each other and attending to each other's needs. Darwin thought that the social instincts would be of two sorts. First, there would be those impulsive instincts, such as anger, and secondly, there would be the more calm and persistent social instincts that do not have the same immediate force, such as love for one's children. ${ }^{19}$ He thought that, as man developed intellectually, he would come to realize that, if he were to help others, he might receive help in return (contemporary evolutionary biologists refer to this concept as reciprocal altruism) (Richards 1999, 143; also Darwin 1871, 72-73).

An important feature of Darwin's account of the genesis of morality is that moral action is not motivated by self-interest, but rather for concern for the overall welfare of society-he admits that moral action might well not be in the interest of the individual. In this sense, Darwin's theory would oppose contractarians, such as Hobbes, who suggested that man enters into moral society motivated by selfinterest, because pre-moral life would be intolerable (Hobbes 1960). Darwin had read John Stuart Mill's Utilitarianism (which came out two years after the Origin), but also disagreed with Mill that moral action was (or should be) executed in order to maximize total aggregate happiness. Rather, Darwin thought that moral action happened spontaneously, guided by our social instincts. Though utilitarianism does not necessarily require conscious deliberation for

18 One of the most important developments in evolutionary biology in the past thirty years has been the ability to account for Darwin's ideas without abandoning individual selection.

${ }_{19}$ Interestingly, Darwin's observations are consistent with Hume's theory of the passions. Hume, like Darwin, posited a metaphysical and phenomenological difference between anger, which he classified as an original passion and love, which he classified as a secondary and indirect passion. Hume also posited another group of secondary passions, the direct passions, which could be either calm or violent. 
moral action (or conscious application of the hedonic calculus), it is interesting to observe that Darwin thought that morality could be entirely instinct driven. Oddly, Darwin thought that intellect necessarily gave rise to the moral sense but, once the moral sense came into existence, he seemed to think that it was self-propelling and no longer had a need for the intellect.

I think that Darwin's ideas on morality have been dramatically undervalued. In fact, many of his ideas have anticipated current developments in sociobiology. What I personally find most exciting about his ideas is that he does not commit the naturalistic fallacy, which we shall encounter later in this paper. Many of the other evolutionists who have tried to develop ethical systems have committed logical errors that have rendered their theories useless, but Darwin does not. The reason is that he has fairly modest goals: to explain the genesis of morality. Nowhere in his ethical writings does offer normative guidance; rather, he is interested in the development of man's moral sense. I think that, as an evolutionist, this is exactly the right approach and one that Herbert Spencer and others would have been wise to follow. Darwin's work on ethics is certainly not systematic, and it leaves a lot of important questions unanswered. But his primary thesis, that man's moral sense is a product of evolution, is one should be appreciated and considered. I will now turn to Darwin's contemporary, Herbert Spencer, who had far more lofty goals for his evolutionary ethics, and whose work has been heavily criticized.

\section{Herbert Spencer}

Though Darwin was certainly interested in morality, it was obviously not his primary investigation. Herbert Spencer, Darwin's fellow Englishman, was the first evolutionist to seriously question the ethical implications of evolution and, in fact, all of Spencer's many published volumes culminated in his Principles of Ethics (Spencer 1873a). Spencer, who was a well-known and respected philosopher in his time, wrote on a wide variety of topics with the ambition of creating a 'Synthetic Philosophy'; to this end, he wrote The Principles of Biology, The Principles of Sociology, The Principles of Sociology, all of which went on to be textbooks used at major universities. However, Spencer thought that all of these works were foundational for his work on ethics. As evidence of this, he suspended work on further volumes of his Principles of Sociology because he feared that he 
may not live to complete his work on ethics. As he wrote in his autobiography:

I begin to feel that it is quite a possible thing that I may never get through both the other volumes of the Principles of Sociology, and that, if I go on writing them, and not doing anything towards the Principles of Morality till they are done, it may result in this last subject remaining untreated altogether; and since the whole system was at the outset, and has ever continued to be, a basis for a right rule of life, individual and social, it would be a great misfortune if this...should remain undone (Spencer 1904, 369-370).

And, as he wrote in the preface to the Principles of Ethics, 'To leave this purpose unfulfilled after making so extensive a preparation for fulfilling it, would be a failure... of which I do not like to contemplate' (Spencer 1873a, 31-32). There is certainly no doubt as to the importance the Spencer placed upon the working out his ethical system; what remains to be seen is why he thought that all of his other work led towards this end.

Unfortunately, the legacy that Spencer has left is not one that is tremendously favorable. Contrary to his hopes, his ethical system has not endured as he would have liked and, even worse, was almost instantly criticized upon its deliverance by well-known thinkers such as T.H. Huxley, ${ }^{20}$ Henry Sidgwick ${ }^{21}$ and G.E. Moore (Moore 1903). Furthermore, Spencer is most often remembered for his coinage of 'survival of the fittest' (which Darwin used interchangeably with 'natural selection' in the $5^{\text {th }}$ and 6th editions of The Origin) and his Social Darwinism (which has nothing to do with Darwin and would be more aptly named Social Spencerianism). These ideas have led many to think that Spencer's ethics are decidedly unethical; consider his following remarks against the British poor-laws:

Besides an habitual neglect of the fact that the quality of a society is physically lowered by the artificial preservation of its feeblest members, there is an habitual neglect of the fact that the quality of a society is lowered morally and intellectually, by the artificial preservation of those who are least able to take care of themselves...For if the unworthy are helped to increase, by shielding them from that mortality which their unworthiness would naturally entail, the effect is to produce, generation after generation, a greater unworthiness (Spencer 1873b).

20 Huxley, who had a close friendship with Spencer before the two got in a disagreement about ethics, criticized Spencer's views in numerous writings and private correspondences. The most significant attack on Spencer's position, however, came in Huxley's well-attended Romanes lecture at Oxford. This lecture is entitled 'Evolution and Ethics' and appears in (Huxley 1896-1902).

21 Sidgwick condemns Spencer's position most directly in Sidgwick 1902), but also in his more famous The Methods of Ethics (Sidgwick 1907). 
Finally, both 'survival of the fittest' and Social Darwinism have been negatively associated, whether fairly or unfairly, with various eugenics movements, most notably that of Nazi Germany.22

For these reasons, many might consider Spencer's project, that of developing a system of ethics based on evolution, to be a failure. If this were true, it would still be important to discuss Spencer's views, both because they are historically important and, perhaps more relevant to the philosopher, because we can learn from his failures and perhaps use them as a guide to developing a more successful system of evolutionary ethics. However, several contemporary commentators have been dubious as to whether or not Spencer's views should be so easily dismissed. ${ }^{23}$ Just because eugenicists have appealed to Spencer is not a reason to assume that he was wrong; they may have, and most likely did, misunderstand his theory. Furthermore, even if they did not, blaming Spencer for penning the ideas that later underscored their movements would be tantamount to blaming Galileo for the advent of aerial bombing. As to the more substantive criticisms of his ethics, especially by Sidgwick and Moore, it can plausibly been argued that they attack a caricature of his position rather than his actual position; if this were true, the criticisms would obviously be ineffective. Finally, as to the criticism that Spencer was unsympathetic to the plight of the poor, it could plausibly be argued that it was precisely because of his sympathy for the poor that he was so opposed to the British welfare system; I will discuss this possibility below. With a compassion for Spencer's tarnished legacy and an optimism that his ethics has been historically undervalued, I now turn to a discussion of his theory. 24

Spencer's ethics was based upon the principle that the moral end of man was happiness. He had two separate arguments for this claim. First, he thought that claiming any other end would result from a

22 As Hitler wrote in Mein Kampf, 'He who wants to live must fight, and he who does not want to fight in this world where eternal struggle is the law of life has no right to exist'; this statement (and others) has been given as evidence of Hitler's endorsement of 'Spencer's views', which Hitler seems to have misunderstood or, at a minimum, misrepresented. See (Bullock 1991, 141).

23 (Richards 1987) is a brilliant book that includes, in addition to a detailed historical survey of evolutionary ethics, a positive account that might be loosely construed as neo-Spencerian. Also see (Thomson 1995 and 1999, 473-484).

24 It should be noted that Spencer's moral theory, though most explicitly discussed in The Principles of Ethics, had been formulated in several volumes, spanning backwards to Social Statics and over thirty years. Furthermore, his writing lacks the tight argumentation that most contemporary analytic philosophers would (understandably) find attractive. For these reasons, getting a hold of his ethical theory is somewhat like 'rather like trying to grab a fat eel.' (Richards 1987, 308). Nevertheless, I believe that presentation that I offer fairly captures the central tenets and is uncontroversial. 
confusion between means and ends and, secondly, he thought that all other ethical systems either explicitly or implicitly endorsed Mill's Greatest Happiness Principle (Richards 1987, 305). However, Spencer objected to the idea that humans either did or, more importantly, should consciously try to maximize the happiness brought about by their actions. ${ }^{25}$ Rather, Spencer thought what contributed to the maximization of happiness was social evolution (i.e., the evolution of society). Though this position need not be at odds with Mill's utilitarianism, which need only be committed to idea that the rightness of an action is determined by whether or not it maximizes happiness and can by silent as to the psychological mechanism that leads to the agent's action (e.g., rational deliberation or evolved intuition), 26 it is important to observe the importance that Spencer is already beginning to place upon evolution as being central to the potential for moral action.

Though Spencer endorsed the Greatest Happiness Principle, it is useful to distinguish his position from Mill's. Spencer certainly thought that happiness was the ultimate end of man, but he thought that this happiness was to be found in justice and the individual's acquisition of the maximal freedoms consistent similar freedoms for all (rather than in hedonistic pleasure as Mill thought). Because of this belief, Spencer thought that an ethical system should have as its aim the achievement of the state of affairs consistent with justice and maximal freedoms for all, since these concepts were inextricably linked to happiness. The reason that justice is so important is that Spencer thinks that freedoms will follow from it (as opposed to slavery, which is unjust and restrictive of freedoms). But why are freedoms important? Spencer thought that maximal freedoms would allow for the greatest variability on which evolution could act and that this variability, in turn, would provide the necessary means to bring about improved states of affairs in the world (Thompson 1999, 476).

\footnotetext{
25 Because of this objection, Mill labeled Spencer an 'anti-utilitarian' in his 'Utilitarianism', which ran in serial form in Fraser's Magazine during 1861. Through private correspondence, Spencer assured Mill that he did not dispute the Greatest Happiness Principle, and only wished to make the comment that man neither did nor should consciously pursue maximization of happiness. Since this latter belief did not necessarily run contrary to anything that Mill was arguing for, Mill seemed appeased and commented as such in a lengthy footnote when Utilitarianism was published in its entirety in 1863.

26 Contemporary moral theorists often draw a distinction between a 'standard of right and wrong' and a 'decision procedure.' Spencer and Mill can both be read as assenting to utilitarianism as a standard of right and wrong (i.e., both agree that the right action is the one that maximizes happiness). What Spencer means to deny, however, is that commitment to the Greatest Happiness Principle suggests a decision procedure (i.e., he would deny that it follows from the fact that we should maximize happiness that we should consciously try to maximize happiness). For an important articles on this distinction, see (Railton 1984).
} 
This belief partially followed from his Lamarckianism (the belief that acquired traits could be inherited), but an example can help us see why he would think this way. Imagine that, because of restricted freedoms, all of the members in society were more or less the same (i.e., they all ate the same things, worked at the same factory, lived in similar accommodations, had the same educations, etc.). Because of their similarities, there would be little that evolution could give us in the second generation other than more of the same (assuming the persistence of background conditions). Thus, no development (physical, intellectual, etc.) would ensue. Now, consider a highly diverse society whose individuals differed in all the ways that they were similar above. In this society, given differential survival and reproductive rates, evolution would produce future generations in which the more highly adapted individuals came to dominate and the less adapted individuals ceased to exist. As individuals became more highly adapted, they would have more freedoms (physical, intellectual, etc.), which would translate into more 'happiness'.27

Spencer thought that there were three evolutionary ends of human conduct which furthered the ultimate goal of equal freedom (Spencer 1873a, 58-60; Richards 1987, 304). First, there was the goal of selfpreservation; behaviors were evolutionarily superior if they contributed to the fitness of the agent. Secondly, behaviors were evolutionarily superior insofar as they contributed to the fitness of one's progeny. And, finally, actions that contributed to overall societal welfare would also be favored by evolution-this followed from Spencer's partial adherence to group selection. Though each of these three claims may be uncontroversial, it was Spencer's next step that was the ambitious one: he endeavored to show that these evolutionary ends were also moral ends. If that were true, then he thought that evolutionary laws would also be moral laws and therefore require our acquiescence (Richards 1987, 304). In order to show that these evolutionary ends were also moral ends, he tried to show how their pursuit (i.e., the pursuit of the health and safety of the individual, his progeny, and his society) would tend to increase happiness in the world. As I discussed above, he thought that happiness was the ultimate end and so, if he could show that the ends of evolution contributed to happiness, then he thought that he

\footnotetext{
27 As Moore would point out, it is not clear why we should think that greater freedom ensures greater happiness. To borrow Mill's example, consider Socrates (who has many freedoms) contrasted with a pig (who has fewer). However, suppose that Socrates is unhappy, whereas the pig is not (at least as measured in terms of quantity of pleasure if not quality). See Moore 1903, 51-52.
} 
would have established the necessary link between evolution and ethics.

Spencer argued that evolution furthered happiness by observing that individuals of most worth, as measured by their fitness to the conditions of existence, shall have both the greatest benefits, and that inferior individuals shall receive smaller benefits, or suffer greater evils, or both' (Spencer 1873a, 2:25). This certainly seems right; individuals that are better adapted to their environments are happier (and enjoy greater freedoms), than those that are less adapted to their environments. Since evolution leads to higher degrees of adaptation, it would also lead to greater happiness. Furthermore, as Richards nicely observes, 'organisms would generally be led to engage in lifesustaining acts through the allure of pleasure; those individuals who found that life-sustaining activity generally and consistently produced misery would cease the struggle for existence' (Richards 1987, 306307; Spencer 1873a, 1:118).

For these reasons, evolution brings with it greater happiness and, therefore, shares the same end as morality. Therefore, Spencer thought, evolutionary laws were also moral laws.

It is also interesting to investigate Spencer's thoughts on altruism; he discussed the topic at length and reasonably thought that altruism was a necessary hallmark of moral behavior. ${ }^{28}$ Furthermore, Spencer's discussion on altruism is especially important given that he is often criticized for comments that he made regarding the British poor-laws which are perceived to be decidedly opposed to altruism yet nevertheless allegedly follow from his moral theory. Spencer conceived of different types of altruism, the most basic of which was family altruism. Parents who were not sufficiently altruistic to their children would run that their children would not reproduce. This lack of altruism, if heritable, would lead to the 'disappearance from future generations of the nature that is not altruistic enough-so decreasing the average egoism' (Spencer 1873a, 1:234) Conversely, altruistic parents would beget children who would be more likely to reproduce and thus the incidence of altruism (again assuming its heritability) would increase in the general population. ${ }^{29}$ Spencer also discussed

28 Spencer defines altruism as any action, unconscious or conscious, that 'involves expenditure of individual life to the end of increasing life in other individuals'; we might be more inclined to define altruism as a personal sacrifice for the benefit of another. (Richards 1987, 310).

29 We might also note that overly altruistic tendencies would vanish over time since those who were overly altruistic would be at a reproductive disadvantage as compared with those who were only properly altruistic. As Spencer remarked, 'every species is continually purifying itself from the unduly egoistic individuals, while there are being lost to it the unduly altruistic individuals.' (Spencer 1873a, 1: 234). 
societal altruism (as opposed to the more narrow familial altruism), and gave two arguments as to why it would develop (Richards 1987, 310). First, Spencer appealed to group selection. He thought that the society that was less altruistic would do less well off than an altruistic society, and therefore be selected against. In the future, altruistic societies, given differential advantages relative to non-altruistic societies, would come to dominate. Secondly, he thought that members of society would be inclined toward altruistic behavior because 'other-regarding actions conduce to self-regarding gratifications by generating a genial environment' (Spencer 1873a, 1:241) Spencer therefore thought that rational individuals would, at times, act altruistically toward non-family members because of these gratifications and the prospect of a favorable environment. $\mathrm{He}$ summed up his attitude toward altruism under the more general law that if the constitution of the species and its conditions of existence are such that sacrifices, partial or complete, of some of its individuals, so subserve the welfare of the species that its numbers are better maintained than they would otherwise be, then there results a justification for such sacrifices' (Spencer 1873a, 23, emphasis added).

Given that Spencer thought that altruism was morally justified, it seems confusing that his attitudes toward the poor have been so heavily criticized. I think that these criticisms mark one of the most common misinterpretations of Spencer's philosophy. Of course, he does not help himself with quotes such as the following:

We must call those spurious philanthropists, who, to prevent present misery, would entail greater misery upon future generations. All defenders of a poor-law must, however, be classed among such...Blind to the fact that under the natural order of things, society is constantly excreting its unhealthy, imbecile, slow, vacillating, faithless members, these unthinking, though well-meaning, men advocate an interference that not only stops the purifying process, but even increased the vitiation-absolutely encourages the multiplication of the of the reckless and incompetent by offering them an unfailing provision, and discourages the multiplication of the competent and provident by heightening the prospective difficulty of maintaining a family (Spencer 1851, 323-324, emphasis in original).

Though such passages (and there is no shortage) have been received quite critically, there is no reason to think that Spencer manifested any animosity or ill-will towards the less fortunate. Rather, I think that he is best interpreted as merely making a critical social commentary on the state of the British poor-laws during his time. ${ }^{30}$

${ }^{30}$ For a similar interpretation, see Ruse 2001, 74-5; Richards 1987, 302-3. 
Spencer's primary objection was that the system was constructed in such a way that people had every incentive to qualify for benefits and no incentive to pursue their own livelihoods (he did not object to benefits for the elderly or those otherwise unable to work). Furthermore, he thought that unfair restrictions were placed upon those who had to pay into the system since those who worked subsidized those who did not. In all, this process would consist in social devolution since, over time, skills and motivations would atrophy. Since Spencer thought that social evolution was morally incumbent upon society, he thought that social devolution was obviously immoral, as were its constitutive practices.

In general, Spencer favored any laissez-faire political scheme over any of its rivals since he thought that freedom was one of the chief constituents of happiness, which was the ultimate moral end and, furthermore, state intervention would impede social evolution (Farber 1994, 41-42; Richards 1987, 303). The problem with the poor-laws was thus two-fold: they both fostered devolution and restricted personal liberties by mandating compulsory payments into the system (by the affluent). As we saw above, Spencer thought that altruism would be justified if it were to increase total aggregate happiness. Therefore, we could conclude that he would be of the opinion that forced altruism would rarely serve this function. Spencer was certainly not opposed to philanthropy, merely the forced kind. Two of his most famous disciples, John D. Rockefeller and Andrew Carnegie donated exorbitant sums to charity; Rockefeller tithed to his church, to general charities, and the University of Chicago, whereas Carnegie gave extensively to the development of public libraries (Ruse 2001, 75-76). These are the sorts of altruism that Spencer would adamantly support: by contributing to the intellectual and spiritual health of society, social evolution would surely follow.

What should we take from Spencer's evolutionary ethics? First, we should appreciate his attempt to forge a link between evolution and morality. Whereas Darwin was primarily interested in describing the biological origins of the moral sense, it was Spencer who first searched for moral justifications for evolution. Secondly, I think that we should recognize that Spencer's ideas have been often misunderstood and historically undervalued. Finally, and most important philosophically, his central thesis that evolutionary laws are moral laws is one that warrants more discussion. It was this thesis that his critics were quick to attack and on which the plausibility of evolutionary ethics largely hangs. I will now turn to those critics. 


\section{Thomas Henry Huxley}

Thomas Henry Huxley is perhaps most commonly remembered as an ardent defender of evolution; he allegedly once referred to himself as 'Darwin's Bulldog' and the moniker has certainly stuck. Darwin was incredibly averse to controversy and confrontation and, because of this and his suspect health, was far more inclined to stay at home to write than to publicly champion his causes. Huxley, however, eschewed neither controversy nor confrontation, and it was often him that publicly spoke out in defense of evolution. ${ }^{31}$ Undoubtedly the most famous of these defenses came at the Oxford meeting of the British Association in 1860, just a few months after the publication of The Origin. At this meeting, the young Huxley debated evolution against Bishop Samuel Wilberforce. As an observer of the encounter recalled almost forty years later, Wilberforce went first and:

In a light, scoffing tone, he assured us there was nothing in the idea of evolution; rock-pigeons were what rock-pigeons had always been. Then, turning to his antagonist with a smiling insolence, he begged to know, was it through his grandfather or his grandmother that he claimed his descent from a monkey?

\section{Shortly thereafter:}

Huxley slowly and deliberately arose. A slight tall figure, stern and pale, very quiet and very grave, he stood before us and spoke those tremendous words which no one seems sure of now, nor, I think, could remember just after they were spoken, for their meaning took away our breath, though it left us in no doubt as to what it was. He was not ashamed to have a monkey for his ancestor; but he would be ashamed to be connected with a man who used great gifts to obscure the truth. No one doubted his meaning, and the effect was tremendous. One lady fainted and had to be carried out; I, for one, jumped out of my seat. ${ }^{32}$

Though the details may be somewhat contentious, historians certainly take this debate to constitute one of the most important events in the course of the popularization of evolution. ${ }^{33}$ This is the

${ }^{31}$ It is a matter of ongoing debate just how much Huxley bought into natural selection, that he took evolution to be true is obvious, but some doubt is left as to the mechanism to which he subscribed.

32 'Grandmother's Tale,' Macmillian's Magazine 78 (1898): 425-435. Leonard Huxley, Thomas's son, draws off this report when giving his account in Life and Letters of Thomas H. Huxley (New York: D. Appleton, 1900) 1: 197-202.

33 No less significant was John Scopes 'Monkey Trial' which took place in Tennessee in 1925 (also less well-known as State of Tennessee v. John Scopes). In this trial, John Scopes was prosecuted for teaching evolution in a public school. The trial pitted Clarence Darrow, a famous defense lawyer, against William Jennings Bryan, former U.S. congressman and three-time Democratic presidential nominee. 
case not so much because of the actual content of the debate, which is somewhat comical, but because of the symbolic significance: Huxley, at age thirty-five and already well-respected, challenges Wilberforce, twenty years his senior, and both welcomes evolution and levies a public and humiliating insult. This certainly affected the psychological dimension of the evolution debate, as some became more wary to identify with the aged and beaten anti-evolutionist while, at the same time, embracing the exciting Huxley and his (and Darwin's) evolution.

Though this anecdote compromises the entirety of most people's knowledge of Huxley, he is also a significant figure in our discussion of evolutionary ethics. Huxley became more interested in ethics later in his career, and his views quite conspicuously opposed those of Spencer, though Huxley rarely mentioned Spencer by name. In fact, the two had been very close friends for many years until a rift developed between them in regards to some of Huxley's ethical work; Huxley partially thought that Spencer had accused him of plagiarism and partially thought that Spencer acted condescendingly in his refusal to criticize some of the conclusions that Huxley had drawn from common starting points (Richards 1987, 314-316). Though the two reconciled shortly before Huxley's death, it was their disagreements over ethics that led to their serious, though perhaps immature, break in friendship. In earlier writings, Huxley took issues with Spencer's endorsement of a laissez-faire political system, arguing instead for public education for the lower classes (Huxley 1871, 251289). However, these disagreements culminated in Huxley's celebrated Romanes lecture at Oxford in 1893 in which Huxley made thinlyveiled criticisms against Spencer and, more generally, was extremely critical of the plausibility of deriving normative legitimacy from evolution. It is from this lecture that we can gain the best insight into Huxley's moral views.

However, before turning to Huxley's Romanes lecture, it can be illustrative to look at how his ethical views were formed. In 1860, Huxley's son Noel died and, in 1887, his favorite daughter Marian died. Though Huxley was deeply affected by the deaths of both children, Marian's death was especially hard on him; many of those around him noticed severe (and lasting) emotional changes in him. Furthermore, it came at a time when he was beginning to do his work

Though Scopes lost the trial, Darrow certainly got the better of Bryan, who was repeatedly humiliated. Consequently, the evolutionary theory began to garner more support by the American public. Incidentally, Scopes was fined a mere $\$ 100$, which was never collected. 
on ethics, beginning with essays in the same year and culminating in his Romanes lecture six years later. There is no doubt that these deaths, and especially Marian's, deeply affected Huxley's ethical views. In particular, he saw that nature was indifferent to human life and wrote that it was hard to take solace in 'the reflection that the terrible struggle for existence tends to final good, and that the suffering of the ancestor is paid for by the increased perfection of the progeny' (Huxley 1888, 198). He had already begun to question Spencer's claim that evolution and morality aimed at the same ends-the loss of his children had convinced him that nature could be mean and unjust and there were certainly not the ends at which morality aimed. These observations led to the formation of Huxley's core moral belief, that since nature (and therefore evolution) could be decidedly immoral, it would follow that moral behavior would consist in opposing the natural processes that led to these unjust outcomes, not embracing it.

In his Romanes lecture, he observed that 'grief and evil fall, like the rain, upon both the just and the unjust'; in the state of nature, the biologically fit survive, but not necessarily the most morally fit (Huxley 1893, 60; Richards 1987, 316). In his most direct opposition to Spencer (and perhaps the most direct exposition of his view), he went on to argue that 'social progress means a checking of the cosmic process at every step and the substitution for it of another which may be called the ethical process the end of which is not the survival of those who may happen to be the fittest... but of those who are ethically best' (Huxley 1894a, 81). Even if, as Darwin thought, the moral sentiments had evolved, evolution could only 'teach us how the good and evil tendencies of man may have come about; but, in itself, it is incompetent to furnish any better reason why what we call good is preferable to what we call evil that we had before' (Huxley 1894a, 82).

When Huxley published his Romanes lecture, he added a lengthy prolegomena which included an extended metaphor in which he hoped to clarify his central point (Huxley 1894b, 35). In this prolegomena, he argued that ethical and cosmic (i.e., natural) processes were antagonistic. His example was horticultural; he asked the reader to imagine the perfect garden from both the aesthetic (i.e., moral) point of view and to compare this to the garden that was in the grasp of natural law. The garden that was left to its own natural devices would, of course, develop weeds, attract parasites, etc. These would, in turn, lead to the gradual deterioration of the ideal garden. However, the ardent horticulturist would oppose these natural processes and, in so doing, improve the status of the garden. Thus the better garden is the one in which the natural law is opposed. Huxley's 
metaphor, excepting his somewhat hasty slide from aesthetics to morality, purports to be a fairly straightforward demonstration of the opposition that exists (at least sometimes) between the moral law and the natural law. Given this opposition, Huxley thought, we must oppose the natural law (including evolution) if we are to be moral. And, though Huxley did not explicitly argue that this opposition was omnipresent, we can safely assume that he thought it to be so. Therefore, morality requires continuous battle against natural forces, of which evolution is certainly a large constituent. Huxley makes his conclusion explicit: 'Let us understand, once and for all, that the ethical process...depends, not on imitating the cosmic process, still less in running away from it, but in combating it' (Huxley 1894a, 83).

What should we take from Huxley? Like Spencer, Huxley was one of the early thinkers of his bent; whereas Spencer tried to derive moral directives from natural law, Huxley tried to show that such a derivation was impossible. Huxley certainly deserves some credit the perspective that he contributed (he was, after all, a scientist more than a philosopher), even if we might find his argumentation suspect. Specifically, we may find his metaphor to be wanting-some might think that his analogy is quite weak or otherwise ineffectual. However, his failings, if any, are not of tremendous philosophical interest since his ideas (and most importantly his attacks on evolutionary ethics) will be furthered by later thinkers, most notably Henry Sidgwick and G.E. Moore. Since these philosophers will provide similar but stronger ideas and incorporate more rigorous argumentation, I propose to suspend evaluation of Huxley's critique until the stronger versions are on the table.

\section{Henry Sidgwick, G.E. Moore, and the Spirit of David Hume}

The entrance of Henry Sidgwick into the debate on evolutionary ethics is extremely significant. First, the criticisms that he would ultimately provide of any attempts to derive normativity from evolutionary laws are ones that survive intact to this day and, in many people's eyes, are the Achilles' heel of evolutionary ethics. ${ }^{44}$ Though these same ideas achieved more clear exposition in the works of G.E. Moore, it was Sidgwick who first provided them. While it is certainly true that Sidgwick's ideas derived, in some sense, from the work of

34 For an optimistic view, see Ruse (1986). Farber (1994) is more representative. 
David Hume over a century earlier, it was Sidgwick who was the first to successfully bring these ideas to bear on evolutionary ethics. For these insights, he is deserving as a central figure in the history of evolutionary ethics. Secondly, Sidgwick's entrance into the debate plays an important symbolic role: it is the first time that a moral philosopher (as opposed to a natural scientist) has considered attempts at evolutionary ethics. Moreover, it was not just any moral philosopher, but rather Henry Sidgwick, the Knightsbridge Chair of Philosophy at Cambridge University, one of the most exclusive posts available to any moral philosopher. Sidgwick was arguably the second most important moral philosopher of the second half of the nineteenth century (behind Mill), and the fact that he found evolutionary ethics to be a topic to which to devote some of his attention was certainly noteworthy.

Moore, who was Sidgwick's student and later became a professor at Cambridge, followed Sidgwick in his discussions of evolutionary ethics. If anything, Moore's status exceeds that of Sidgwick's since Moore's Principia Ethica is quite likely the most important book written in moral philosophy in all of the twentieth century. Sidgwick and Moore's entrance to the debate marks an important shift: it demarcates a transition from evolutionary ethics as the dominion of the natural scientist to evolutionary ethics as the dominion of the moral philosopher.

The cynic might argue (correctly) that both Sidgwick and Moore thought that all attempts to derive evolutionary ethics were hopelessly flawed. In both of their writings, Spencer (who they rightly took to be the contemporary flag-bearer of evolutionary ethics) is practically ridiculed; both philosophers were very harsh towards Spencer and his would-be followers. However, the point remains that evolutionary ethics made an important transition (if perhaps not a successful one) from the realm of science to the realm of philosophy. Both Spencer and Huxley wrote sprawling works with little in the way of argumentation; the advent of the moral philosopher would signal an end to such sloppy methodology. If evolutionary ethics was going to be plausible, it would have to be approached in a manner different than the way that it had been approached in the past. This would certainly be an improvement. Furthermore, the ideas that Sidgwick and Moore offered (and which hearkened back to Hume) are critical to any further investigation.

Sidgwick first became interested in Spencer's ethical ideas in the first edition of his Methods of Ethics (1874). At the publication of the first edition, Sidgwick still had to go off of Spencer's Social Statics 
since Principles of Ethics was not published until almost twenty years later. Spencer's ethical views developed from Social Statics through The Data of Ethics and culminated in the Principles of Ethics, the final two-volume work. Sidgwick's subsequent editions of the Methods of Ethics reflected the development of Spencer's ethical thought, continuing all the way through Sidgwick's final edition, the seventh, which was released over thirty years after the first. However, though the Method of Ethics was Sidgwick's most important work, it was his lectures at Cambridge in which he levied his most direct and substantial criticisms against Spencer. ${ }^{35}$

In these lectures, Sidgwick has three principal complaints about Spencer's ethical theory. The first, which had already been made in the first edition of the Methods of Ethics, was that Spencer's theory only provided for the moral principles of an ideal society and was therefore of very little use in reality; he lamented that Spencer's ideas could have only an 'indirect and uncertain...relation to the practical problems of actual life' (Sidgwick 1907, 18; Richards 1987, 320). Sidgwick, who aimed to harmonize classical utilitarianism with intuitionism, often expressed his frustration with moral theories which found little application in the real world, and he thought that Spencer's theory was one of these.

There are, however, numerous responses that Spencer might have been inclined to make to this objection. First, since this first criticism appeared early enough to afford Spencer a chance at a response, we might consider what Spencer actually said. Spencer's answered Sidgwick by invoking a distinction that he had made as early as Social Statics, which was that between 'relative ethics' and 'absolute ethics'. Spencer thought that absolute ethics governed moral action in the ideal society, whereas 'relative ethics' offered us the rules that would be of pragmatic use in our (not ideal) society. Spencer was willing to acknowledge that, though part of his theory aimed at providing absolute ethics (and was therefore victim to Sidgwick's criticism), he had also attempted to provide a system of relative ethics which could be used in actual societies. Sidgwick, however, was equally disapproving of Spencer's relative ethics, which he thought offered little more than 'moral bromides' (Richards 1987, 320).

The second response that Spencer could have made (and most ironic given Sidgwick and Moore's ultimate criticism) is that moral philosophy need not be concerned with the real world at all; moral

\footnotetext{
35 These have been republished as Lectures on the Ethics of T. H. Green, Mr. Herbert Spencer, and J. Martineau (Sidgwich 1902).
} 
philosophy aims to give us ideals to which we should strive. If the central tenets of a moral theory (such as Spencer's which advocated equal justice and freedom for all) are not of the sorts that can be readily applied to pressing social issues (such as euthanasia or international trade tariffs), this need be a problem for the theory itself, but merely unfortunate for those of us who do not know how to apply it. To further a discussion to which I alluded earlier, consider classical utilitarianism. Critics have argued that utilitarianism is unhelpful (or, even worse, wrong!) because it is impossible for man, with limited knowledge and limited cognitive capacities, to apply Bentham's hedonic calculus at every turn. But the limited pragmatic value of such a theory has nothing to do with whether the theory correctly demarcates the difference between right and wrong action. It might well be the case that such a theory correctly identifies a standard of right and wrong but that an agent cannot apply the theory; in this case he may have to incorporate heuristics, rules of thumb, etc. Even if we do agree that ethical theories should ultimately be pragmatically applicable rather than purely academic discussions of right and wrong (which is not an admission that I would be inclined to make), it does not follow that theories of the latter characterization are wrong, nor that they cannot offer some, albeit limited, guidance.

Sidgwick's second objection was more compelling: he asked how Spencer proposed to justify the connection between the ends of evolution and the ends of morality. If evolution aimed at the development of natural life, and morality aimed at maximal happiness, what reason was there to think that these two goals coincided? (Richards 1987, 321) Of course, Spencer had tried to show that both evolution and morality took as their end the greatest happiness (which Spencer understood not as maximal pleasure but rather as realization of justice and freedom), but his arguments which aimed to substantiate the claim that the end of evolution was happiness were quite shaky. Sidgwick went on to point out that it might well be the case that ethical dilemmas might arise in which the moral agent must adjudicate between the life and happiness of one and the life and happiness of another: 'What is to be done if two ends-Life and Happiness-do not coincide, in any particular case, here and now? and whose Life (or Happiness) is to be taken as standard by the individual, if circumstances arise in which a choice has to be made between action conducive to his own Life (or Happiness), and action conducive to the Life (or Happiness) of others?' (Sidgwick 1902, 217) Spencer's theory gives us no insights as to how such an adjudication should proceed (Mill's utilitarianism, by contrast, does). 
Again, however, this criticism is one of application of the theory, rather than one of the theory itself. Though Spencer did not respond explicitly to these complaints of Sidgwick, it seems that Spencer would say that, for example, in choosing whether to save one of two drowning people, the morally correct action would be the one that maximizes overall happiness (i.e., freedom and justice). Unfortunately, Spencer's conception of happiness leads to more complex quantification than Mill's hedonism but there is no reason why, in principle, such a quantification could not proceed.

Sidgwick's third objection is clearly the most important and, furthermore, the one on which Moore would expound. Of Spencer's theory, Sidgwick asked 'Why am I to seek the Greatest Happiness?' (Sidgwick 1902, 219) Sidgwick, we might assume, was willing to grant Spencer's (dubious) biological assumption that evolution tended towards the greatest happiness but it was not clear to Sidgwick how anyone could possibly think that moral action consisted in accommodating this trend. To create an analogy, we might look at one of the more common laws of physics, gravity, and observe that gravity tends to make objects fall towards the ground. Now, it would certainly seem quite odd to infer from this that it is morally incumbent upon anyone to assist in things falling to the ground!

Sidgwick thus thought that there was a 'gap in ethical construction' between physical law and moral law; as Richards remarks, Sidgwick thought that 'the 'oughtness' of moral principles depended upon no empirical conditions for its force' (Richards 1987, 322) (such as natural law). Though both Spencer and Sidgwick agreed that happiness was the ultimate end, Sidgwick thought that only reason could supply the necessary moral justification for the pursuit of happiness-the contingent coincident end of both moral action and evolution was insufficient warrant for the moral legitimacy of evolution. Relatedly, he thought that facts (such as the fact of evolution) were unable to produce moral imperatives. Unfortunately (and oddly), Sidgwick did not explain why he thought this was the case, nor did he provide a substantial defense of his claim that Spencer's ethical theory leaped over a 'gap'.

Fortunately, a young G.E. Moore was in attendance at Sidgwick's Spencer lectures, and Moore did not hesitate to drive Sidgwick's point home, thus coining the 'naturalistic fallacy' and, arguably, sounding the death knell for evolutionary ethics. In Principia Etbica, which was published in the same year the Spencer died, 1903, Moore devoted considerable attention to Spencer's views. For Moore, 'good' was a simple (i.e., not constructed of parts), non-natural (i.e., not 
determinable or measurable by any empirical means), undefinable property whose presence was to be intuited. Spencer, who held that 'good' could be understood as 'the greatest happiness' or, more specifically, 'maximal freedom for all', had already run afoul of Moore's conception of 'good' by thinking that any more information could be given about its nature. But, even worse, the definition that Spencer offered for 'good' invoked natural concepts, 'happiness' and 'freedom'. Both happiness and freedom can be, at least in some way, empirically investigated and measured (e.g., happiness could be measured by serotonin release in the brain, whereas freedom could be measured by the number of acts available to the agent). It was in virtue of this latter infraction that Moore was especially critical.

Moore accused Spencer of committing the naturalistic fallacy, which consists in 'identifying the simple notion which we mean by 'good' with some other notion.' (Moore 1903, 58) The equation of 'good' with 'happiness' or 'freedom' was, Moore thought, such a fallacy. In order to convince readers of this, he offered the 'open question argument'. This 'argument' proceeded by observing that, if 'good' meant the same as 'promotes happiness', the question 'I know that $\mathrm{x}$ is good, but does $\mathrm{x}$ promote happiness?' would be as nonsensical as asking 'I know Jack is a bachelor, but is he an unmarried male?' It is precisely because 'bachelor' means 'an unmarried male' that the second question is silly. And, according to Moore, the reason that the first question does not share the strangeness of the second is because 'good' does not mean the same as 'promotes happiness' - since we can meaningfully ask whether the good promotes happiness, 'good' cannot be defined in terms of promoting happiness.

A very related line of reasoning had appeared earlier in the work of David Hume, who famously wrote that:

In every system of morality, which I have hitherto met with, I have always remark'd, that the author proceeds for some time in the ordinary way of reasoning, and establishes the being of a God, or makes observations concerning human affairs; when of a sudden I am surpriz'd to find, that instead of the usual copulations of propositions, is, and is not, I meet with no proposition that is not connected with an ought, or an ought not. This change is imperceptible; but is, however, of the last consequence. For as this ought, or ought not, expresses some new relation or affirmation, 'tis necessary that it should be observ'd and explain'd; and at the same time that a reason should be given, for what seems altogether inconceivable, how this new relation can be a deduction from others, which are entirely different from it. But as authors do not commonly use this precaution, I shall presume to recommend it to the readers; and am persuaded, that this small attention wou'd subvert all the vulgar systems of morality, and let 
us see, that the distinction of vice and virtue is not founded merely on the relations of objects, nor is perceiv'd by reason (Hume 1978).

In short, Hume argued that it was logically impossible to move from a set of purely factual premises to a normative conclusion. For example, the argument:

P1) Killing takes a human life.

C) Killing is (at least prima facie) wrong.

is invalid; the truth of the conclusion is in no way necessitated by the truth of the premise. Some further premise, such as 'It is (at least prima facie) wrong to take the life of a human', would be necessary to make the argument valid. In valid arguments (and excepting logicians' tricks such as addition), the content of the conclusion already appears, in some form, in the premises and, a fortiori, the transition from factual premises to a normative conclusion (with its introduction of normative concepts) will violate this requirement.

'Hume's Law', as it has come to be known, is potentially violated by Spencer's ethical system. As some commentators have tried to argue, Spencer's argument might be fashioned as follows:

P1) Evolutionary law aims at the survival of the fittest.

Moral law aims at the survival of the fittest.

Needless to say, this argument is obviously invalid. And, if this argument adequately represents Spencer's views, then Spencerian ethics should be rejected outright; this is the thrust of Hume's Law as brought to bear on evolutionary ethics.

There is, of course, a tremendous literature on both Moore's naturalistic fallacy (and his associated open question argument) as well as on Hume's is/ought gap. Notable philosophers, such as John Searle and Philippa Foot, have downright denied Hume's central claim,36 whereas numerous criticisms have been launched against Moore. Nonetheless, the point that they sought to make has become entrenched as one of the central tenets of moral philosophy which, even with some detractors, has been tremendously influential.

It is clear that Moore's criticisms signaled the beginning of a long slumber for evolutionary ethics. As I said, Spencer had died the same year of Moore's publishing, and was consequently unable to respond

\footnotetext{
36 See Searle 1964. Foot has argued this idea variously, see especially Foot 1958. Many important papers have been reassembled in Hudson 1969.
} 
to Moore (even if he would have had some potential response to offer). Furthermore, nobody came to his defense; Moore's criticism seemed so compelling that all parties involved figured that the sun had set on evolutionary ethics. Aside from further criticism from American pragmatists William James and John Dewey, ${ }^{37}$ repeated missteps from Julian Huxley, the who did not share the pessimism towards evolutionary ethics of his grandfather (Huxley J. 1943), and the modest contributions of the unknown C.H. Waddington (Waddington 1942), there was little industry in evolutionary ethics for nearly three quarters of a century, until the advent of sociobiology.

As I said at the beginning, the verdict is still out on the revival phase of evolutionary ethics, but the historical legacy that it must take as its starting point is not favorable. Not surprisingly, the next generation (with the exception of Robert Richards) has largely abandoned Spencerian attempts to derive normative conclusions from evolutionary law, and has instead chose to focus on the possibility of evolution contributing to morality at a meta-ethical level. ${ }^{38} \mathrm{Or}$, in other words, most attempts have centered around the potential of evolution to explain certain features of morality rather than to justify substantive moral conclusions. Regardless, the historical results garnered by the above thinkers have shaped the current landscape and will continue to delineate the prospects of evolutionary ethics in the future.

\section{References}

Barrett, P. H. et al. (eds.), 1986, Charles Darwin's Notebooks, Ithaca: Cornell University Press.

Brown D., 1991, Human Universals, Boston: McGraw-Hill.

Bullock A., 1991, Hitler and Stalin: Parallel Lives, London: Harper \& Collins.

Darwin C., 1859, On the Origin of the Species, London: John Murray.

Darwin E., 1803, The Temple of Nature, London: J. Johnson.

Darwin F. (ed.), 1969, Life and Letters of Charles Darwin, 3 vols., New York: Johnson Reprint Group.

Dawkins R., 1982a, The Extended Phenotype, San Francisco: Freeman, Cooper, and Co.

Dawkins R., 1982b, The Selfish Gene, Oxford: Oxford University Press.

Dewey J., 1898, 'Evolution and Ethics', The Monist, 8.3: 321-341.

Farber P.L., 1994, The Temptations of Evolutionary Ethics, Berkeley: University of California Press.

\footnotetext{
37 For a nice overview, see Weiner 1949. See also James 1920 and Dewey 1898.

38 See for example Ruse 1986b.
} 
Foot P., 1958, 'Moral Beliefs', Proceedings of the Aristotelian Society, 59.1: 83-104.

Galton F., 1865, 'Heredity Talent and Character', Macmillan's Magazine, 12: $157-$ $166,318-327$

Hobbes T., 1960, Leviathan, Oxford: Blackwell.

Hudson W.D. (ed.), 1969, The Is-Ought question: A Collection of Papers on the Central Problems in Moral Philosopby, London: McMillan and Co.

Hume D., 1960, A Treatise of Human Nature, Shelby-Bigge L.A. (eds), Oxford: Oxford University Press.

Hume D., 1978, A Treatise of Human Nature, $2^{\text {nd }}$ ed., Shelby-Bigge, Nidditch P.H. (eds), Oxford: Clarendon Press, III.I.i.

Huxley J., 1943, Evolutionary Ethics, Oxford: Oxford University Press.

Huxley L., 1900, Life and Letters of Thomas H. Huxley.

Huxley T.H., 1871, 'Administrative Nihilism', Collected Essays, 1: 251-289.

Huxley T.H., 1888, 'The Struggle for Existence in Human Society', Collected Essays, 9: $195-236$.

Huxley T.H., 1893, 'Evolution and Ethics', Collected Essays, 9: 46-116.

Huxley T.H., 1894a, Evolution and Ethics, London: MacMillan and Co.

Huxley T.H., 1894b, 'Evolution and Ethics: Prolegomena', Collected Essays, 9: 145.

Huxley T.H., 1986-1902, Collected Essays, 9 vols., New York: D. Appleton.

James W., 1920, Collected Essays and Reviews, London: Longmans, Green.

Moore G.E., 1903, Principia Ethica, Cambridge: Cambridge University Press.

Railton P., 1984, 'Alienation, Consequentialism and the Demands of Morality', Philosopby and Public Affairs, 13.2: 134-171.

Richards R., 1987, Darwin and the Emergence of Evolutionary Theories of Mind and Behavior, Chicago: University of Chicago Press.

Richards R.J., 1999, 'Darwin's Romantic Biology: Evolutionary Ethics'. In: Maienschein J., Ruse M. (eds), Biology and the Foundations of Ethics, Cambridge: Cambridge University Press: 113-153.

Ruse M., 1986a, 'Evolutionary Ethics: A Phoenix Arisen!', Zygon, 21.1: 95-112.

Ruse M., 1986b, Taking Darwin Seriously: A Naturalistic Approach to Philosopby, New York: Blackwell.

Ruse M., 1999, 'Evolutionary Ethics: What Can We Learn from the Past?', Zygon, 34.3: 435-451.

Ruse M., 2001, The Evolution Wars: A guide to the Debates, New Brunswick: Rutgers University Press.

Searle J., 1964, 'How To Derive an 'Ought' from an 'Is', The Philosophical Review, 73.1: $43-58$.

Shelby-Bigge L.A. (ed.), 1960, A Treatise of Human Nature, Oxford: Oxford University Press.

Sidgwick H., 1902, Lectures on the Ethics of T.H. Green, Mr. Herbert Spencer, and J. Martineau, London: MacMillan.

Sidgwick H., 1907, The Methods of Ethics $7^{\text {th }}$ ed., London: MacMillan.

Sober E., 1984, The Nature of Selection, Cambridge, MA: Cambridge University Press.

Spencer H., 1851, Social Statics: Or, the Conditions Essential to Human Happiness Specified, and the First of Them Developed, London: J. Chapman.

Spencer H., 1873a, Principles of Ethics, 2 vols., Indianapolis: Liberty Classics 1978.

Spencer H., 1873b, Study of Sociology, Ann Arbor: University of Michigan 1961.

Spencer H., 1898, Principles of Ethics $2^{\text {nd }}$ ed, 2 vols., New York: Appleton. 
Spencer H., 1904, Autobiography, 2 vols., New York: D. Appleton.

Thompson P., 1995, Issues in Evolutionary Ethics, Albany, NY: State University of New York Press.

Thompson P., 1999, 'Evolutionary Ethics: Its Origins and Contemporary Face', Zygon, 34.3: 473-484.

Waddington C.H. (ed.), 1942, Sciences and Ethics, London: George Allen and Unwin.

Weiner P., 1949, Evolution and the Founders of Pragmatism, Cambridge, MA: Harvard University Press.

William G., 1966, Adaptation and Natural Selection, Princeton, NJ: Princeton University Press.

Wilson D.S., 1989, 'Levels of Selection: An Alternative to Individualism in Biology and the Human Sciences', Social Networks, 11: 257-272.

Wilson D.S., Sober E., 1994, 'Re-introducing Group Selection to the Human Behavioral Sciences', Behavioral and Brain Sciences, 17: 585-654.

Wilson D.S., Sober E., 1998, Unto Others: The Evolution and Psychology of Unselfish Behavior, Cambridge: Harvard University Press.

Wilson E.O., 1975, Sociobiology: The New Synthesis, Cambridge: Harvard University Press. 